\title{
Austrian Security Policy Documents - a Walk on a Tightrope between Neutrality and International Solidarity
}

\author{
Wolfgang $\mathrm{ZECHA}^{1}$
}

\begin{abstract}
After achieving the Vienna State Treaty, Austria had to develop its security policy missing fundamental documents. The first main document was the constitutional law on neutrality, which was passed by the Austrian parliament on $26^{\text {th }}$ October,

1955. Even before that, the Austrian defence law was approved on $5^{\text {th }}$ September,

1955. Although Austria promised in the Moscow Memorandum to pursue a neu-trality policy like Switzerland, the Austrian policy left this line by becoming a mem- ber of the UN in 1955. So the Austrian security policy started to walk a tightrope between neutrality and international solidarity because of her UN membership and membership in other organisations like EU or NATO Partnership for Peace (PfP) later on. This essay emphasizes the steps of amendments, which were made in the Austrian constitution and her policy during almost 60 years with respect to international security policy and Austrian participation in international opera- tions. The aim of this essay is to point out the new understanding of international solidarity of "neutral", Austrian policy.

But it is necessary to stress the main points of neutrality and what that meant in international security policy from a legal point of view.
\end{abstract}

Keywords: Austria, neutral Austrian Security Policy, Austrian contribution to peacekeeping

\section{Introduction}

The status of neutrality was defined within the "Land Warfare Regulations" which were signed during the Conference of The Hague 1899, and confirmed in the Conference of The Hague 1907. Therefore neutrality in general exists only in wartime and the practice of neu- trality policy was formulated following the policy Switzerland had practised since the end of the Napoleonic Wars and that kind of practise was granted by the Treaty of Versailles 1919 . Following the Land Warfare Regulations of 1899 the main points of neutrality policy are:

1. A neutral country cannot take part in war.

2. A neutral country cannot allow foreign troops to use its territory in any case.

3. A neutral country cannot help any parties in a conflict.

4. A neutral country has to defend its own territory. [1: 14]

Pursuing those principles, neutrality policy means to make sure, that on the one hand a state has to avoid any act, which could lead to an involvement in a conflict. On the other hand,

1 Austrian National Defence Academy, Vienna, e-mail: wolfgang.zecha@bmlvs.gv.at 
a neutral state can act in a conflict, but it has to make sure that all parties to a conflict or even a war have to be handled equally. Therefore, it is impossible for a neutral state to be part of a defence or common security organisation.

Another difference, which hast to be pointed out at the beginning is the difference between neutrality and neutrality policy. Neutrality means a general behaviour of a country towards any possible situation in security threats. Neutrality policy on the other hand emphasises concrete acting in a certain security environment and/or situations relevant to security issues.

This essay deals with Austrian neutrality policy with respect to its membership in inter- national organisations, the amendments of its legal framework pursuing the consequences of its membership in international organisations dealing with security issues, and the Austrian policy taking part in international operations.

Originally, there was only one type of neutrality, neutrality in wartime. Within the last 90 years rules and types of neutrality developed and therefore today there exist the following types of neutral countries: [2: 23]

a) permanent neutral countries like Switzerland or Austria;

b) traditional neutral countries related to international law or non-alignment; that non-alignment can be practised also in peacetime, being neutral in war time, like Swe- den or Finland did after 1955;

c) neutralistic, non-alignment, or active peace-making countries like India, Egypt, Ghana, Yugoslavia did in the1950s.

But during the last 60 years, some additional types of neutrality like "active" or "realis- tic" neutrality were introduced. But in general, a neutral country has to stand aside from all wars and to make sure that it does not support one side in a conflict. But there is no interna- tional written law on how to practise permanent neutrality policy, but a permanently neutral country should practise a policy in advance like a neutral country does during a current conflict. [3: 55] Therefore permanently neutral countries like Austria and Switzerland have to pursue a security policy in peacetime in a way so they can withstand a conflict in the neighbourhood or anywhere in the world without being involved. If a country undertakes the obligation to be neutral in all future conflicts, than that country has to make it clear that it will not fight against anybody or support any party to the conflict. That obligation ends if a country is attacked and has to defend itself. [4: 93]

The article is structured into four parts:

1. Austrian neutrality policy from 1955 to the end of the 1960 s.

2. Active neutrality policy during the 1970s up to the end of the "Cold War".

3. Struggling for Integration: Austrian EU-membership and membership in NATO PfP.

4. Muddling Through: Austrian Security Policy after the Financial Crisis. In the end, results and recommendations will be formulated.

\section{Austrian Neutrality Policy from 1955 to the End of the 1960s}

As it was mentioned above, Austria left the path pursuing the Swiss model by becoming a member of the UN at the end of 1955. The UN Charter describes the UN as an all-inclu- sive Organisation "...to maintain international peace and security, and to that end: to take effective collective measures for the prevention and removal of threats to peace, and for the suppression of acts of aggression or other breaches of the peace..." [5: 8] Therefore, the 
articles of the UN Charter allow taking compulsory measures towards any "peace breaker". All member countries have to co-operate in preventing and suppressing threats to the peace and acts of aggression. Nobody is allowed to be neutral towards a country, which is a "peace breaker" in the eyes of the Security Council (SC) or the General Assembly (GA).

At that time, a debate started in Austria (and internationally) whether or not the UN and its bodies have to be aware of the neutrality policy of certain members and act according to this status. The Austrian member of the international court at The Hague, Alfred Verdross, presented the following thesis:

"Austria has become a UN member as a neutral country, so the UN and its bodies have to be aware of this status. In other words, neutrality law beats UN law." [6: 90]

Later on, this thesis was called "Verdross Doctrine". Pursuing that thesis, even each mea- sure, passed by the UN SC, had to be passed autonomously by the parliament of a neutral country. During the Rhodesian crisis that policy was pursued by all European neutral coun- tries. ${ }^{2}$

The Austrian defence law, passed by the Austrian parliament on $5^{\text {th }}$ September, 1955, listed only three tasks for the Austrian Armed Forces:

a) protection of the borders;

b) protection of constitutional institutions and maintenance of order and security in general;

c) assistance in the case of natural disasters or accidents of extraordinary dimension. [7] No assignment for international operations was foreseen at that time. Some main princi- ples followed this practice, and were laid down as the Austrian Neutrality Policy by Foreign Minister Leopold Figl in 1959. He listed the following points of Austrian neutrality policy:

a) supporting the right of self-determination for peoples, understanding among nations, law and justice, civil and human rights, basic liberties, and the practical implementa- tion of these principles;

b) hosting international organisations and agencies;

c) strengthening international co-operation;

d) cultural exchange. [8: 293-303]

There was no intention of participating in or conducting international operations, despite the fact that such operations had been going on in Korea, Kashmir, or Palestine since 1948. Looking back from today, the only kind for such an amendment of Austrian neutrality policy could have been the point "strengthening international co-operation" in Figl's principles of 1959.

But in August, 1960, the Secretary General (SG) of the UN, Dag Hammarskjöld, made a request to the Austrian government for a contribution of Austria to the UN operation in the Congo. Foreign Minister Kreisky was aware of the fact that there was no legal background to participate in international operations. He was convinced that a positive feedback to the UN request will have a positive impact on the international reputation of Austrian policy. A week later the request was approved by the Austrian Council of Ministers (ACM). It is remarkable that a main argument in favour of participation in the mission was a foreseeable reduction of the Austrian membership fee to the UN. [9] When Austria started to take part in international operations, no governing Austrian Acts of Parliament existed. Austrian soldiers had to sign

2 Austria, Finland, Ireland, Switzerland, and Sweden 
a special contract to participate in the international operation in the Congo (1960-1962). It is remarkable that there was no discussion on the accordance to neutrality in Austria. The reason maybe was that Switzerland had taken part in an international operation following the Korean War in 1953, so it was a proven practise for neutral countries.

In 1964, Austria participated in a second international operation on Cyprus. Therefore, it became necessary to establish a national law for conducting international operations. That need was supported or even urged by a verbal note of the SG of the UN. This note said that it would be helpful to have a national legislative procedure to conduct international operations. [10: 181] On 30 June, 1965, the Austrian Parliament passed a constitutional law [11] to conduct international operations. Following this constitutional law, the Austrian government was only allowed to conduct international operations with the approval of the Main Committee of the Austrian National Council. Secondly, a request of an international organisation was necessary and the Austrian government had to respect the requirements of permanent neutrality. A remarkable feature of this law was that any international organisation could request a contribution to its operation. In the law neither the type of aid nor the type of international organisation (neither NATO nor the Warsaw Pact could have done that) was fixed.

In Austria, the government also worked on a general Defence Doctrine. By a decision of the ACM on $11^{\text {th }}$ May, 1965, the cases of threat were defined as:

1. Crisis as a result of international tensions and threat of conflict;

2. Neutrality in case of war in the region;

3. Defence after an attack on Austria. ${ }^{3}$

It was remarkable that "international operations" were not mentioned in that doctrine, despite Austria having taken part in at least two international operations before 1965. After defining the threats, it took an additional ten years to pass the Security doctrine.

During this period, Austria participated in two international operations, the operations in Congo (ONUC) from 1960-1962 and the operations in Cyprus (UNFICYP) from 1964 to $1972^{4}$ only with medical personnel. In 1960 and 1964, armed troops were denied by the government for neutrality reasons. ${ }^{5}$

For a neutral country another major problem is how to handle sanctions, mandates or measures passed by the SC. The first time this happened was during the South Rhodesian crisis in the 1960s. In the year 1966 the SC imposed economic measures following the uni- lateral declaration of independence of South Rhodesia. [6: 61] The SC informed all countries, whether or not they were members of the UN that they had to obey the measures towards South Rhodesia. Austria answered that it would examine each decision of the SC or GA on its own to decide whether or not to follow the measures. The Austrian parliament passed, some days later, a move by the government to implement measures towards South Rhodesia which

3 1. Krisenfall als Zustand internationaler Spannungen und Konfliktgefahr, 2. Neutralitätsfall mit einem Krieg in der Nachbarschaft und 3. Verteidigungsfall bei einem Angriff auf Österreich, in Bayer Richard, Die Geschichte der Umfassenden Landesverteidigung, Vom Staatsvertrag bis zur Wende, Schriftenreihe der Landesverteidigungsakademie, 2 (2008)S, 12-13. (Sonderpublikation)

4 In 1972, the contingent was extended to an armed battalion. The medical centre was withdrawn in 1976. The battalion was opened to other nations in the 1990s: Today, Austria participates in that operation with four staff officers.

5 In both cases Austria was asked to send armed troops by the UN SG, but for neutrality reasons only medical and postal personnel was granted. 
were like the measures passed by the SC - it was a move to show independence, but at the same time to act in solidarity with and according to the Verdross doctrine. Austria mentioned in its reply to the UN that Austria would conduct the same measures as the SC but only under a national law because of its neutrality.

To summarize, Austria conducted a policy of solidarity within the UN by participating in UN operations (with unarmed contingents) and pursuing UN SC measures by autonomous decisions. It is remarkable that in 1964, Sweden insisted that at least one additional neutral country should take part in the operation for it to send her troops also. So this mode of neu- trality policy has also been handled by the other European neutral countries until the end of the Cold War.

\section{Active Neutrality Policy during the 1970s up to the End of the "Cold War"}

After Bruno Kreisky became Chancellor in Austria he started to develop a new kind of neu- trality policy, he called it "active neutrality policy". Even though the concept of this kind of policy had been thought of in 1955, Bruno Kreisky defined it as a concept. The main instru- ments of this policy were: [12: 807-808]

a) active policy within international organisations;

b) foreign policy initiatives;

c) offering "good duties";

d) offering diplomatic negotiations and conferences;

e) offering as a site of international organisations;

f) strengthening of international law;

g) blaming violations of international law.

It was a fact that the active neutrality policy of Bruno Kreisky was favoured by the inter- national policy of détente during the 1970s, which brought a window of opportunity for small and neutral countries. As a first step in the direction of active neutrality policy Austria extend- ed her contingent to UN Cyprus operations (UNFICYP) by armed troops on $3^{\text {rd }}$ May, 1972. Previously, the Austrian diplomat Kurt Waldheim was elected UN SG and took over this post on $1^{\text {st }}$ January, 1972. In 1972, Austria applied, and was elected, as a non-permanent member to UN Security Council (UN SC) for a first period, 1973/74. During those two years, Austria went, additionally, into UNEF II ${ }^{6}$ operations, which were transferred to UN Disengagement Observer Force (UNDOF) ${ }^{7}$ operations in 1974.

During his chancellorship, Bruno Kreisky started a lot of diplomatic initiatives like the diplomatic offensive towards Eastern Europe, the "fact finding missions" to Israel and the Palestine Liberation Organisation, or the initiative towards the Arab Countries and the OPEC (Organization of the Petroleum Exporting Countries), the last one decided to install its site in Vienna. Austria was one of the founding nations of the CSCE/OCSE (Conference on Security and Cooperation in Europe/Organisation on Security and Cooperation in Europe) and Vienna has been also one of the cites of CSCE/OCSE from the very beginning.

6 UN Expeditionary Force to separate Israeli and Egypt armed forces after the Yom-Kippur-War.

7 Austria withdrew her troops in 2013 as a result of the Syrian civil war and because of the imprecise mandate to handle this situation. 
But during that phase, the domestic affairs also developed. For instance, the National Defence Plan was written and brought to a decision in that time. To write a comprehensive defence plan or doctrine started shortly after the independence of Austria. Originally the Swiss model was pursued and in 1965 the threats for Austrian security were defined as fol- lows: [13: 6-8]

1. Crisis as a result of international tensions and threats of conflict.

2. Neutrality in case of war in the region.

3. Defence after an attack on Austria. ${ }^{8}$

A working group was installed and ten years later, in 1975, the Austrian constitution was amended by article 9a, which contemplated "comprehensive national defence". But although the Austrian Armed Forces (and also Forces of the Ministry of Interior) had participated in international operations for approximately 15 years, the Austrian legislative had not thought about an additional article to legalize international operations at that time. Late in 1977, the Constitution was amended again, integrating international operations as a task for the Austrian Armed Forces. So 17 years after the first Austrian participation in an international operation - and 12 years after a law to conduct international operations, such tasks were formally legalized for the Austrian Armed Forces by the Austrian parliament, amending the Austrian Constitution

In 1983, the Comprehensive National Defence Concept was passed by the Austrian Par- liament and it is still in force in Austria, supplemented by the Security Doctrine 2001, the Comprehensive Security Provisions 2006, and the Security Strategy 2013.

Again, the legal basis in Austria followed her proven practise: Austria went into interna- tional operations - and a certain number of years later, the responding laws were passed by the parliament. From the point of view of Austrian neutrality policy practice, there were the following changes during the period of "active neutrality" policy:

a) participating in international operations by armed troops;

b) making policy to achieve armistices, even in more dangerous operations;

c) extending international policy by achieving a high post in international organisations (e.g. UN SG, etc.);

d) extending to UN cite in Vienna;

e) applying for a domicileof other or new international operations (UN, Organization for Security and Co-operation in Europe [OSCE], IAA, OPEC, etc.);

f) starting negotiations with "outlaws" of the international community (Palestine Liberation Organization [PLO], Muamar al Gaddafi, etc.);

g) extending good duties "all over the world".

To summarize that period, Austria went into different international operations, legalized her participation in international operations on a constitutional level, was member of the UN SC, nominated for the UN SG for two periods, started a certain number of diplomatic initia- tives and extended the international site of Vienna.

8 1. Krisenfall als Zustand internationaler Spannungen und Konfliktgefahr, 2. Neutralitätsfall mit einem Krieg in der Nachbarschaft und 3. Verteidigungsfall bei einem Angriff auf Österreich. [13: 12-13] (Sonderpublikation) 


\section{Struggling for Integration: Austrian EU-Membership and Membership in NATO PfP}

After the Austrian 1986 elections the internal situation changed. The "Era Kreisky and his active neutrality policy" was definitely finished. The new Foreign Minister, Alois Mock, chair of the Austrian Peoples Party (APP), reoriented the security and foreign policy back to European affairs. [13: 822-823] He promoted "realistic" neutrality policy that meant from his point of view: to stay away from international conflicts, if possible. On the other hand, the new Minister of Defence, Werner Fasslabend, orientated the Austrian Armed Forces towards international operations by forcing e.g. language training. The Austrian economy got more and more interwoven with the European Economic Community (EEC), which was develop- ing dynamically in that time. Simultaneously, the Austrian economy suffered from the crisis, which aimed especially at the industrial sector of Austrian economy. Therefore, especially the APP, favoured a membership in the later European Union and NATO as well. Consequently, the Austrian Ministerial Council decided to apply for membership on $29^{\text {th }}$ June, 1989, and Foreign Minister Alois Mock handed over the application for membership to the EEC to the French Presidency of the European Council, Foreign Minister Roland Dumas on $17^{\text {th }}$ July,

1989; only a few days before the historical 1989 change happened in Europe. The member states of the EEC were worried about the neutral status of the new applicants (Austria, Fin- land, and Sweden) and so they urged for a clear statement from these countries concerning their security and defence policy in the future. During the negotiations from 1993 to 1994 the three countries had to abandon the reservation of neutrality. The EEC demanded from the three countries assurances that after their accession to the EEC these states would execute a future Common Foreign and Security policy (CFSP), which appeared only as a thought in the Treaty of Maastricht in 1992. [14: 87] Therefore, in the accession treaty Austrian neutrality was not mentioned any more. This development meant a clear departure from the previous line of Austrian neutrality policy back to the route of a core neutrality policy, which meant neutrality in case of war. Sweden and Finland decided to declare that they would not be neu- tral any more, They explainedthat they will act for the future like non-aligned States .

The change of 1989, the fall of the Berlin Wall and the Iron Curtain, brought a window of opportunity to a lot of European countries. The breakdown of the Soviet Union in 1991, gave freedom to the Eastern European countries under former USSR overlay, and to some of its former republics. The implication on Austrian security policy was an orientation to European integration and a change of neutrality practise. Later on, the later Austrian chancellor Wolf- gang Schüssel described the Austrian neutrality policy after 1995 with the following proverb: "Austrian foreign policy will be solidarity within the European Union (EU) and neutrality outside of it."

But there was another change in Austrian neutrality policy in those days. On $2^{\text {nd }}$ August, 1990, the Iraqi Armed Forced invaded neighbouring Kuwait. Because Kuwait had only a weak army, the Iraqi Armed Forces occupied the " $19^{\text {th }}$ province of Iraq" within days. The day the occupation started, the UN SC - including the neutral member Finland - passed resolution 660 condemning the occupation, and called for immediate withdrawal and nego- tiations. On $29^{\text {th }}$ November, 1990, the UN SC authorized all nations co-operating with the Kuwaiti government to use all means to implement Resolution 660, unless Iraq implemented 
the resolution fully on or before $15^{\text {th }}$ January, 1991 (Resolution 678). ${ }^{9}$ Austria granted over- flight rights following Resolution 678 for all airplanes of the coalition, again together with a reservation of neutrality. Switzerland closed its air space for military planes for reasons of neutrality, an important difference to Austria's position. [6: 70-72] On 16 ${ }^{\text {th }}$ January, 1991, the air strikes started, and on $24^{\text {th }}$ February, 1991, the ground attacks began from Saudi territory. The attacks were so successful that the Iraqi government surrendered on $3^{\text {rd }}$ March, 1991.

The implication of the liberation war in Kuwait was for Austrian neutrality policy: Austria left the Verdross Doctrine and moved to a new policy concerning UN SC measures, the later so-called "Ermacora Doctrine": 10 "UN SC measures are to be implemented because they can be seen as police actions and therefore they have no impact on the Austrian neutrality law." [6: 92-94]

With other words: UN law beats (Austrian) neutrality law. Additionally, the Austrian Federal Government decided on $6^{\text {th }}$ November, 1990, to annul articles 12 to 16 and article 22 paragraph 13 of the Vienna State Treaty, ${ }^{11}$ and to notify thereof the signatory states. France agreed, the US signalled their approval for the Austrian point of view and Great Britain and Russia ${ }^{12}$ did not have any objections to it either.

As a result of the end of the Cold War and the liquidation of the Warsaw Pact, NATO enlarged its organisation and founded NATO Partnership for Peace in 1994. It is a bilater- al co-operation programme between NATO and individual states to enhance cooperation peace and humanitarian operations. After an internal discussion the Austrian Foreign Minis- ter Mock signed membership to NATO PfP on 10 ${ }^{\text {th }}$ February, 1995. Following this treaties, Austria participated for the first time in NATO-led UN operations, the Implementation Force (IFOR)/ Stabilisation Force (SFOR) operations with a logistics contingent in 1996.

After the accession to EU and NATO PfP, it was necessary to pass an Austrian consti- tutional law to deal with the new situation. 1997, the Austrian parliament passed the law on solidarity and co-operation, which legalized operations and training together with other countries in Austria and abroad. The Treaty of Amsterdam was signed by the Heads of States and Governments on $2^{\text {nd }}$ October, 1997. [15] After the ratification procedure it came into force on $1^{\text {st }}$ May, 1999. By that treaty the WEU became a core part of the EU. Also the Peters- berg Tasks, which were developed and passed by the Heads of States and Government of the WEU in June, 1992, were integrated into the European Common Foreign and Security Policy (CFSP) and European Security and Defence Policy (ESDP). In view of that integration the Austrian Constitutional Law had to be amended by inserting a new article (Article 23f). This article was necessary to make sure that Austria could conduct all operations included in the Petersberg Tasks. The Petersberg Tasks [3: 35] covered:

a) humanitarian operations;

b) search and rescue operations;

9 „Bundesregierung sich dabei von der wachsenden internationalen Solidarität und Mitverantwortung unter Wahrung der Verpflichtungen und Grundsätze leiten lassen wird, die sich aus dem Bundesverfassungsgesetz über die immerwährende Neutralität und der Neutralitätspolitik als stabilisierendem Element der europäischen Ordnung ergeben." http://daccess-dds-ny.un.org/doc/RESOLUTION/GEN/NR0/575/28/IMG/ NR057528.pdf?OpenElement (downloaded: 0204 2011)

10 Felix Ermacora was an Austrian expert on international law and the first expert in Austria to state the supremacy of the UN Charter.

11 These articles concerned restrictions on military weapons (e.g. rockets) and certain relations to Germany.

12 Russia stepped into the rights of the USSR with respect to the Vienna State Treaty. 
c) peace-support operations;

d) peace-making operations including peace-enforcing operations.

During that time, a big debate started in Austria between the leading political parties (the Social Democrats and the People's Party) on the future security policy. The People's Party favoured a possible NATO membership as a further option. The Social Democrats strictly opposed that option. In 1998, an options report concerning the future security policy failed caused by that antagonism.

As we know, the UN had always suffered a lack of troops which could be deployed within a short time. Early in the 1960s the UN SG U'Thant asked the neutral countries to earmark troops for that purpose. Upon that demand the Nordic battalion, composed of Sweden, Den- mark and Norway was founded and earmarked. In Austria, in 1966, a battalion was raised. It was called and designated a UN training battalion, but it was never deployed. In 1994, the time had come to raise a force in accordance with the recommendation of the UN SG Kofi Annan. The UN created a data base for all troops that could be deployed on a mandate of UN SC, the "United Nations Standby Arrangement System" (UNSAS). [16] On $15^{\text {th }}$ December,

1996, Austria, Canada, Denmark, The Netherlands, Norway, Poland and Sweden founded SHIRBRIG - Standby High Readiness Brigade, which had its headquarters near Copenha- gen. The Nordic battalion was integrated into that brigade. It is remarkable, how far neutral countries went, earmarking own troops for international (peace support) operations. Austria contributed to SHIRBRIG mainly by deploying Officers and NCOs for the headquarters. SHIRBRIG was dissolved by $30^{\text {th }}$ June, 2009, mainly caused by the new EU Battle Group Concept and the NATO Response Forces Concept.

The next step in international operations was to participate in a UN peace-making opera- tion. It was also NATO-led and started in 1999. Yugoslavia had been constituted by Josip Broz Tito, the founder of the state after WWII, in 1974, by uniting five republics (Croatia, Mace- donia, Montenegro, Slovenia, and Serbia) and two autonomous regions of Serbia (Kosovo and Vojvodina). The idea to establish these two regions was to strike a balance between the nations of Yugoslavia. That was based on experience after WWI. There had been strong ten- sions between the Serbs and the Albanian population during the 1980s, but after suspension of the autonomy by Slobodan Milosevic the Albanians of Kosovo organised an underground movement and wrote their own constitution in 1992. On 24 ${ }^{\text {th }}$ May, 1992 , elections were held in Kosovo but Serbs did not recognize them. Because of the ongoing suppression of the Albanians in Kosovo an underground army (Ushtria Clirimtare e Kosoves - UCK) was established and began a resistance struggle. The Serbian counter-insurgency operations led to more fighting and after some heavy clashes in autumn 1998, the Serbian police and military forces began to expel the Albanian people. ${ }^{13}$ On $10^{\text {th }}$ January, 1999 , the Serbian forces were accused of perpetrating a massacre at Racak. The negotiations of Rambouillet ${ }^{14}$ failed in February, 1999, and in the aftermath the expulsion of the Albanian people intensified, NATO decided to start air attacks on the Serbian Forces and Belgrade. After two months of bombing, Belgrade withdrew its troops from Kosovo and a NATO-led UN-mandated protection Koso- vo Force (KFOR) were established. [17: 417-420] The genesis of the KFOR operations was

13 The Serbian politicians argued that the situation in Kosovo was an inner-state problem of Serbia. UN SC resolution 1199 spoke of violence towards the Albanian people in Kosovo.

14 Between the US, Great Britain, Germany, France, Italy, and Russia on the one side and Serbia on the other side. 
as follows: Early on $15^{\text {th }}$ February, 1999, Austria was asked if it would participate in a UN operation. There was a decision by the AMC on $9^{\text {th }}$ March, 1999, and after the formal request of the UN SG on $9^{\text {th }}$ June, 1999, the decision was immediately implemented. On $14^{\text {th }}$ June,

1999, it was decided to send an infantry battalion with an approximate strength of 450-500 troops. The Austrian Contingent had certain difficulties to integrate and to fulfil all tasks. The first contingent had certain restrictions in the mandate given by the Austrian government because of Austrian neutrality. The second contingent's mandate was extended, so the con- tingent could at last fulfil all necessary tasks. The Austrian contingent is still a mechanized battalion with APC and even some long range weapons, but no tanks at all. It was the first time, an Austria contingent had to fulfil combat tasks as well as peace support tasks.

After the Austrian 1999 elections, the political situation changed gravely. The Austrian Peoples Party formed a coalition with the Austrian Freedom Party. One result was that the options report was transferred into a security doctrine, which was passed by the Austrian parliament on $12^{\text {nd }}$ December, 2001. [18] The main points were:

a) Key-role of the UN concerning peace and international security; Austria participates in

b) Full support of the CFSP; Peace Support Operations up to brigade-level;

c) Enhanced cooperation with NATO PfP;

d) UN-Charter beats neutrality law;

e) Full participation in European CFSP.

In 2001, the US and the coalition forces attacked the Taliban regime in Afghanistan. The region was secured by the troops of the winning coalition, partly based on a UN mandate. The force was called the International Security Assistance Force (ISAF) in Afghanistan. After the European Council's meeting in Copenhagen in December, 2001, it was clear that every coun- try of the EU would participate in the operation. The Austrian Council of Ministers decided on $10^{\text {th }}$ December, 2001, to contribute a contingent of approximately 70 troops. The mission was passed by the main committee of the National Council in consensus with all parties and there were no discussions at all. It was a NATO-led operation. In the following year, Austria reduced her troops, remaining only some staff officers until the end of the operation in 2014.

To summarize, this period was characterized by major changes in the Austrian security and neutrality policy:

a) Membership in the European Union with full participation in the CFSP;

b) Cooperation in the NATO PfP concerning the full range of Petersberg operations;

c) Full participation in SHIRBRIG;

d) Conducting measures of the UN SC automatically;

e) Neutrality only in cases, if there were no EU or UN decisions;

f) Offering good duties with respect to EU interests;

g) Intensifying domicile-policy for international organisations.

Austria went her way from "active" neutrality to a certain kind of "limited" neutrality and enhanced solidarity. 


\section{Muddling Through: Austrian Security Policy after the Financial Crisis}

After the Austrian 2006 elections the coalition was formed again by Austrian Social Demo- crats and the Austrian Peoples Party. The majorities in the Austrian National Council for the coalitions decreased caused by new parties like Alliance Future Austria, Team Stronach or NEOS. For a long time, the coalition had quarrels concerning security and defence policy; at the moment these differences seem to be clarified, but on a low level caused by the budget restrictions.

But let us start in the year 2008. The government decided to participate in a new opera- tion, led by the EU. The operation was connected with the situation in Darfur, the western part of Sudan. Because of intertribal rivalries and religious differences, thousands of people fled from Darfur across the green border into Chad and the Republic of Central Africa (RCA). But even there the refugees were not safe, because paramilitary troops, for instance the Jan- jaweed, persecuted them. Additionally, drought and crop failures led to starvation among the refugees. The situation escalated in 2007 and even the NGOs could not work without being threatened. To improve that situation the UN SC passed a resolution following chapter VII UN-Charter on $25^{\text {th }}$ September, 2007, concerning the permission to the EU to deploy troops to avoid violence and help against starvation of the people. [19] On 23 ${ }^{\text {rd }}$ October, 2007, the European Council of the EU passed the decision to conduct the operation European Union Force (EUFOR) Chad/RCA under the mandate of the UN SC. That procedure was according to the European Security Strategy (ESS) of December, 2003. On $7^{\text {th }}$ November, 2007, the Austrian Council of Ministers passed a decision to participate in EUFOR Chad/RCA with up to 160 troops for a limited time. In January, 2008, the troops mainly consisting of Special Forces were deployed and came under fire immediately. After the rebels were driven back by French Forces, the international force took over the tasks. Within a year, the operations had calmed the situation and the EUFOR was transformed into the United Nations Mission in the Central African Republic and Chad (MINURCAT). The Austrian contingent was transferred from Special Forces to Logistics. It was the first time, Austria went into an international oper- ation with Special Forces. The EUFOR was a big success, both coalition partners agreed on.

The next on the agenda was to rewrite the Austrian security doctrine, under the new name Austrian Security strategy. The process started in 2010, but it was stopped by a debate on the conscript system, which started in Austria shortly before the day of election of the Vienna Provincial Parliament in October, 2010. From that day on, the coalition partners were in discussion whether or not professional armed forces should be introduced in Austria. Be- cause the coalition partners could not find a solution, there was a vote on $20^{\text {th }}$ January, 2013. The results were $59.7 \%$ conscript army and civil service versus $40.3 \%$ professional armed forces. [20] The new MoD, Gerald Klug, got the task, to improve the conscript system and to make it more attractive for the young soldiers. On the other hand, the armed forces had to suffer budget restrictions caused by the new regulations after the financial crisis. In July,

2013, the Austrian security strategy [21] was passed by the Austrian parliament. The Austrian security policy was subdivided into three levels:

1. the national level;

2. the European level;

3. the international level. 
The national level includes comprehensive security provisions, domestic security, de- fence policy; civil-military cooperation, diplomacy and international site policy. The Euro- pean level encompasses Justice and Interior, CFSP, policy related to the results of the Coun- cils of European Union The international level comprises security of interior, foreign security including UN policy, NATO PfP, OSCE, and international operations. It also stresses the new cyber threats and cyber defence.

The main tasks of the Austrian Armed Forces are:

a) guarantee full state sovereignty and integrity;

b) protect the constitutional institutions and the critical infrastructure;

c) protect the population, also in the area of disaster relief;

d) support the national capacity to act in strategic crisis situations;

e) contribute to the management of crises as an expression of solidarity;

f) make a military contribution to EU security endeavours in the spirit of solidarity.

In the end of the strategy, the criteria for a participation in international operations are defined as follows for a first time:

a) the extent to which the particular situation affects the security of Austria;

b) European solidarity and the importance of the respective activity for the security of the EU or Europe;

c) international solidarity and the importance of the respective activity for global security;

d) the impact participation will have in terms of Austria's position in the organisation in question;

e) the geographical location of the mission in question;

f) the availability of suitable Austrian forces in the civil and military sectors;

g) the financial burdens resulting from participation.

Working on that, in 2014 the Austrian Defence Strategy [22] was passed by the Austrian parliament on.

It defines the Austrian Armed Forces tasks. They have to be able to fulfil tasks to stabilize situations up to robust operations for a certain time frame. Besides that, the Austrian Armed Forces participate in a certain number of peace operations with a maximum of 1200 troops. Also the regions for operations are defined, namely the Balkans, The Black Sea Region, The Middle East, and Northern Africa down to the Sahel Region. Pursuing those tasks the Austrian Armed Forces support EU, UN, OSCE, and NATO operations by troops and staff personnel. But on the other hand, Austria had to reduce her international ambitions from brigade to battalion level.

In the meantime, the Austrian Armed Forces have participated in the United Nations In- terim Force in Lebanon (UNIFIL) operations in Lebanon, and ended UNDOF operations caused by the implications of the civil war in Syria.

Within the approximately last five years, Austria tried to make a policy concerning the CFSP. There was only little room for neutrality policy. The financial crisis brought budget restrictions also for security policy and the Austrian Armed Forces. The Arab spring crisis and the Ukrainian crisis had big implications on the Austrian neutrality and solidarity policy. There is only less room for neutrality policy any more. So Austria backed the sanctions of the EU towards Russia. Austrian Foreign Minister Kurz mentioned at the height of the IS crisis that Austria will join the alliance against IS supporting the Kurds in their struggle to survive. [23] 


\section{Results and Recommendations}

Today this dynamic point of view describes how, usually, in security affairs a (strictly) neutral country acts like someone who jumps on the bandwagon. [24: 121] During the 60 years of Austrian independency after WWII, Austria (and almost all other European neutral countries) developed her neutrality policy to "limited" neutrality, which means:

a) Neutral countries can be members of all UN organisations and sub-organisations, but UN-Charter beats neutrality law. If there are measures against "peace breakers" the neutral country also has to conduct them.

b) Neutral countries can take part in international operations up to robust peace enforcement fulfilling an UN SC mandate.

c) Austria (as Finland, Ireland, and Sweden) is a member of the European Union and takes part in the whole scale of CFSP, but pursuing EU decisions Austria is not neutral any more.

d) Neutral countries can take part in NATO PfP in the full scale of trainings and operations.

In 1955, there was no legal framework in Austria (or elsewhere) on how to live neutrality and solidarity within the UN. Austria developed her legal framework usually after practical steps. The constitution was amended several times, new constitutional laws to participate in international operations had to be passed, and strategic documents had to be written and to be passed by the parliament. Today the security and the defence strategy are documents to give a framework for decision makers whether or not Austria should conduct international measures or operations.

Caused by the Austrian memberships in EU and UN, there is only a very small corridor for neutrality policy any more. So it would be more honest for Austria to make clear that her policy is now more a militarily nonaligned than neutral. But that decision suffers from internal reasons.

\section{References}

[1] VERDROSS, A.: Die immerwährende Neutralität der Republik Österreich. 2. wesentlich erweiterte Auflage, Wien: Österreichischer Bundesverlag, 1966.

[2] ORVIK, N.: Sicherheit auf Finnisch, Finnland und die Sowjetunion. Stuttgart: Seewald Verlag, 1972.

[3] HAUSER, G.: Das europäische Sicherheits- und Verteidigungssystem und seine Akteure. 4. völlig überarbeitete und wesentlich erweiterte Auflage, Wien: BMLV, Landesverteidigungsakademie, 2008.

[4] STOURZH, G.: Geschichte des Staatsvertrages 1945-1955, Österreichs Weg zur Neutralität. 3. Auflage, Graz, Wien, Köln: Styria, Staatsvertrag, 1985.

[5] INTERNATIONAL COURT OF JUSTICE, UN: Die Charta der Vereinten Nationen mit Völkerbundsatzung IGH-Statut und zwei UNO-Resolutionen. 7. neu bearbeitete Auflage. München: Verlag C. H. Beck, 1979.

[6] HANDL, M.: Die immerwährende Neutralität Österreichs. Wien, 2001. 
Wolfgang ZECHA: Austrian Security Policy Documents - a Walk on a Tightrope between Neutrality...

[7] Federal Law Gazette, 181 (1955), $21^{\text {st }}$ September, 1955.

[8] FIGL, L.: Die Diplomatie der Neutralität. In. BRAUNIAS K., STOURZH, G.: Diplomatie unserer Zeit, Graz, Wien, Köln: Styria, 1959.

[9] ZECHA, W.: Der Einsatz des Österreichischen Bundesheeres im Tschad, Reflexion zur Einsatzentscheidung. ÖMZ, 1 (2010), 64-68.

[10] SCHMIDL, A. E.: Blaue Helme - Rotes Kreuz. Innsbruck, Wien, 1995. [11] Federal Law

Gazette, 173 (1965), 933-934.

[12] KRAMER, H.: Strukturentwicklung der Außenpolitik (1945-2005). http://homepage.univie. ac.at/vedran.dzihic/kramer-10.pdf (downloaded: 2612 2014)

[13] BAYER, R.: “Landesverteidigungsplan”. Die Geschichte der Umfassenden Landesverteidigung. Vom Staatsvertrag bis zur Wende. Wien: Landesverteidigungsakademie, 2008. (Sonderpublikation 2/2008/S.)

[14] LUIF, P.: On the Road to Brussels, The political Dimension of Austria's, Finland's and Sweden's Accession to the European Union. Braumüller, Laxenburg: Austrian Institute for International Affairs, 1995.

[15] http://eur-lex.europa.eu/de/treaties/dat/11997D/htm/11997D.html\#0092010003 (downloaded: 2308 2011)

[16] ROSENZOPF, G.: Das war SHIRBRIG. www.shirbrig.dk (downloaded: 1710 2010) [17]

TRUPPENDIENST: Militäroperationen und Partisanenkampf in Südosteuropa. Vom Berliner Kongress zum Ende Jugoslawiens. Wien: Astoria, 2009.

[18] www.parlament.gv.at/PAKT/VHG/XXI/NRSITZ/NRSITZ_0087/fname0rig_114529.htm (downloaded: 2704 2009)

[19] UN SECURITY COUNCIL: Resolution 1778 (200). 25 September, 2007.

[20] www.wien-konkret.at/politik/direkte-demokratie/volksbefragungen/wehrpflicht (downloaded: 0501 2015)

[21] www.bundesheer.at/wissen-forschung/publikationen/beitrag.php?id=2506 (downloaded: 05 $012015)$

[22] www.bundesheer.at/wissen-forschung/publikationen/publikation.php?id=710 (downloaded: 05012015 )

[23] www.parlament.gv.at/PAKT/PR/JAHR_2014/PK0891 (downloaded: 0501 2015)

[24] KERNIC, F., HAUSER G. (Hrsg.): Handbuch zur europäischen Sicherheit. Frankfurt am Main, Berlin, Bern, Bruxelles, New York, Oxford, Wien: Peter Lang Frankfurt, 2005. 